\title{
Evaluation of Antifungal Activity of some Plant Extracts Against Causing Agents of Water- Related Fungal Keratitis
}

\author{
A. S.M. El-Badry', Eman H. F. Abd El-Zaher', K. M. \\ Saad-Allah $^{1}$, Wafaa A. El-Sarnagaway ${ }^{2}$, K.H. Shaltout ${ }^{1}$ \\ ${ }^{1}$ Botany Department, Faculty of Science, Tanta University, \\ and ${ }^{2}$ Egyptian Environmental Affairs Agency, Tanta, Egypt
}

IGH levels of pollutants in the River Nile water caused severe
alteration in the pollutant indicators such as temperature, pH,
dissolved oxygen, chemical oxygen demand, ammonia and nitrate; in
addition to the concentration of some heavy metals (e.g. lead,
mercury and cadmium) which made water unsuitable for drinking,
irrigation and aquatic life. Microbiological results indicated that
Rosetta branch had subjected to sewage pollution with the common
occurrence of Candida pelliculosa, Candida tropicalis, Trichosporon
mucoides and Aspergiulls niger. The infectious mycotic keratitis
among patients of the surrounding residential area was closely related
to the identified yeasts and filamentous fungal isolates from water
samples. Methanolic leaf extract of Melaleuca alternifolia tree
showed a significant inhibition for the most common yeast and
filamentous fungal causative agents, especially against Candida
pelliculosa and Trichosporon mucoides, confirmed with ultra-
structural cellular distortions, that were observed by transmission
electron microscope (TEM). The minimum inhibitory concentrations
(MIC) were also recorded. Melaleuca alternifolia leaf extract was
analyzed by Fourier transformation Infra-red (FT-IR) spectroscopy
and gas chromatography / mass spectrum (GC/MS).
Keywords: River Nile, Pollutant Indicators, Water-Related Infectious Diseases, Candida pelliculosa, Trichosporon mucoides, Melaleuca alternifolia

River Nile is the main source of water for drinking, agriculture, industry, navigation, recreation and fish production in Egypt. Thus, this River is of dominating influence on the economic, cultural, public health, social and political aspects of the country (Rabeh, 2007). Concerning the pollution of Rosetta Branch, there are three main sources which potentially affect and deteriorate its water quality. El-Rahawy Drain pours more than $400 \times 10^{3} \mathrm{~m}^{3}$ daily 
including $398 \times 10^{3} \mathrm{~m}^{3}$ liquid sewage and $2 \times 10^{3} \mathrm{~m}^{3}$ of sludge from Giza Governorate (Ghallab, 2000). At the same time, Sobol Drain at Menofyia Governorate pours its agricultural wastes directly into water current. The second source is Kafr El-Zayat Industrial Area, which includes the industrial effluents from the factories of super-phosphate and sulfur-compounds (e.g. El-Malia Company), oil and soap industries (e.g. El-Malh and Soda Company) and pesticides factory, which pour their effluents directly into water current without any treatment. The third source is many agricultural drains, to which the sewage discharged from many cities and villages that are distributed along the river banks (Abdo, 2002). Water quality of Rosetta Branch may be changed by several factors in the last decades. So, it is important to study the physicochemical characteristics of both water and sediment in the Rosetta Branch (El-Amier et al., 2015a).

Fungi are heterotrophic worldwide spreading microorganisms commonly inhabit many environments in contact with human beings. Certain fungi can inhabit normally the human body surface, which are called human normal microflora. Some fungi inherit, or acquire pathogenic characters and can attack the intact human tissues; while other opportunistic fungi can invade the injured human skin (Shukla and Singh, 1997). Human mycosis is a disease caused by fungi, causing inflammations, and many tissue disorders in different sites within the human body, and thus becoming an important constituent of worldwide public health problems (Rodrick, 2000). Human mycosis can be divided into five categories according to the site of infection and attacked tissues. The first group is the superficial mycosis, growing on the outer surface of skin (e.g. tinea diseases) and mucous membranes (e.g. candidiasis in children). Secondly, cutaneous infections, which can be established within outer layer of skin, decaying and feeding on keratin of nails and hairs. Skin infections are mostly caused by a physiologically distinct group of fungi called dermatophytes, including different species of Microsporum, Trichophyton and Epidermophyton. In addition, third group includes the subcutaneous infections, which invade the living layers of skin, and cause more severe inflammations for living tissues. More deep infections are grouped in the forth category, which cause systemic fungal diseases in different body organs by spore dissemination through the blood stream, and other body fluids (i.e. aspergillosis in lung and cryptococcosis in central nervous system); the fifth group of fungal infections can be separately named ocular mycosis, invading the human eye (Keay et al., 2006).

Mycotic keratitis is a disease caused by fungal invasion into the corneal stroma. It is an exogenous infection, attacking the injured corneal epithelium and establishes the fungal growth within the collagen bound lamellae of stromal layer of cornea. Mycotic keratitis is considered to be a resistant corneal ulcer, which possesses aggressive microbial growth, and becomes not responding to conventional treatments for at least one week or more and even becomes worse due to continued fungal growth (Tanure et al., 2000). The World Health Organization (WHO) stated, in its Global Initiative Vision Report, that about 10 million cases all over the world

Egypt. J. Bot., 56, No. 3 (2016) 
will become blind by the year 2020 due to different resistant corneal ulcers, including those of fungal origin (Gorden, 1999).

Plant extracts can be used as medicinal components that can inhibit pathogenic growth. Studies of plant extracts have been conducted to evaluate the characteristics of natural drug products, including their sustainability, affordability, and antimicrobial activity. A considerable number of studies on medicinal plants and alternative compounds, such as secondary metabolites, phenolic compounds, essential oils and extracts, have been performed (Negri et al., 2014).

Therefore, the present study aimed to evaluate the contamination level of River Nile (Rosetta branch) at Kafr El-Zayat industrial area. Many parameters were estimated, mainly the microbial contamination, for evaluating the relationship between the spread of fungal populations in this main water resource and the incidence of different eye infectious diseases among patients inhabiting the surrounding area. Extracts of ornamental and street trees would be explored as a source of antifungal compounds in a trial to offer a cheap and effective treatment for widely spread fungal infections along River Nile.

Study Area

\section{Materials and Methods}

Sampling process was carried out in winter season (Febraury 2013). Three stations were selected for the collection of water samples (Fig. 1 and 2), sampling point 1 at the front of Kafr Hashad village (before Tala drainage and industrial region drains); sampling point 2 in a common site after the effluent of El-Malia Company (fertilizer producing company which its industrial effluents contain super-phosphate and sulfur-compounds) and El-Malh and Soda Company (oil and soap company which its industrial effluents contain surfactants, oil and soap residues) at Kafr El-Zayat city; and sampling point 3 at the entrance site of Benover village water treatment station.

Water Analysis

Water samples were collected at about $1 \mathrm{~m}$ depth from the three points, using sterilized plastic bottles. The collected samples were stored, refrigerated and analyzed immediately after arrival to the laboratory. For analysis of heavy metals, samples were preserved immediately after collection by acidifying with concentrated $\mathrm{HNO}_{3}$ to $\mathrm{pH}<2$ using $5 \mathrm{ml}$ nitric acid for 1 liter sample. After that, samples were stored in a refrigerator at $4^{\circ} \mathrm{C}$ to prevent change in volume due to evaporation. Samples might be filtered, if necessary, and a portion of the filtered sample was taken for the required determination. Air and water temperatures $\left({ }^{\circ} \mathrm{C}\right)$, electrical conductivity $\left(\mu \mathrm{S} \mathrm{cm} \mathrm{cm}^{-1}\right)$ and hydrogen ion concentration ( $\mathrm{pH}$ value) were measured directly at the sampling stations using portable water quality checker (U-10 HORIBA). Dissolved oxygen was carried out using the modified Winkler method, Ammonia using Nesslerization method, 
Nitrate-Nitrogen using ultraviolet spectrophotometric screening method, and some heavy metals (Lead, Mercury and Cadmium) using nitric acid digestion method (APHA, 2011).

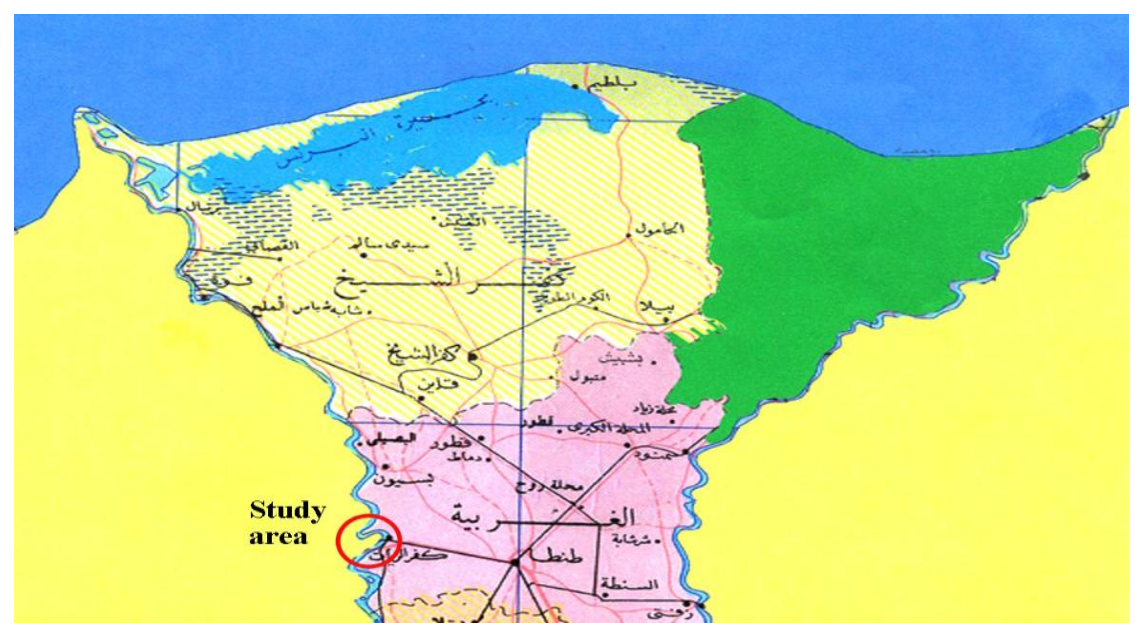

Fig. 1. Map of Nile Delta, showing the study area (Rosetta branch of River Nile at Kafr El-Zayat industrial area).

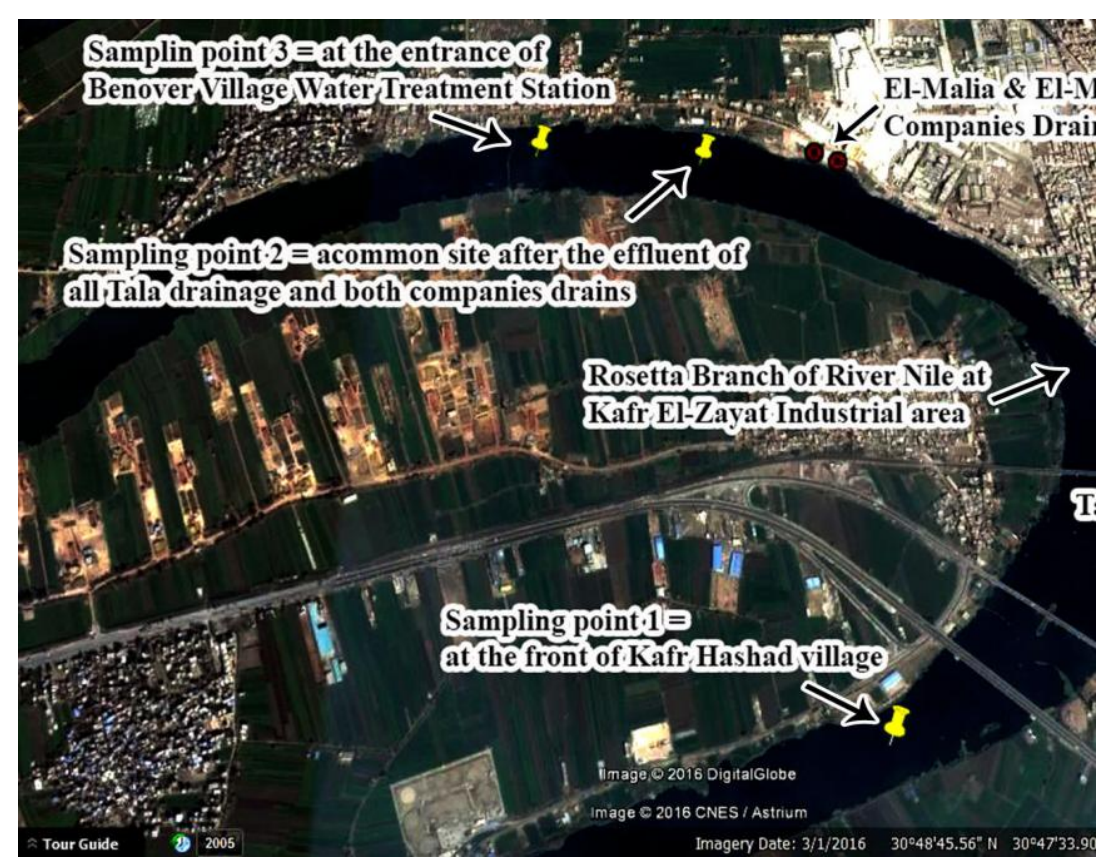

Fig. 2. Representative view for the three points of water sample collection, google earth.

Egypt. J. Bot., 56, No. 3 (2016) 


\section{Microbiological Analysis of Water Current and Keratitis Patients}

Sterile $100 \mathrm{ml}$ plastic bottles were used to collect water samples. Surface plate method (APHA, 2011) was used for determination of the total bacterial count at $37^{\circ} \mathrm{C}$ for $48 \mathrm{hr}$ using Plate Count Agar medium. The plate count technique was used for the isolation and enumeration of fungi (Dutka, 1989), using Aureomycin Rose Bengal Glucose Peptone Agar (ARGPA). Aliquot of 0.1 to 1 $\mathrm{ml}$ of water sample was plated out, and left to be solidified. After solidification, Petri dishes were inverted and divided into two groups, one was incubated at $27{ }^{\circ} \mathrm{C}$ for 3 days and the other was incubated at $37{ }^{\circ} \mathrm{C}$ for $48 \mathrm{hr}$, then the number of colonies were counted on each plate and recorded as $\mathrm{CFUml}^{-1}$. After enumeration, fungal colonies were transferred to Sabouraud's Dextrose Agar plates for identification purposes.

Fungal isolates were collected from infected human eyes during regular once a week visits to the outpatient clinic, and daily follow up visits for patients admitted to Inpatient Department of Ophthalmology Hospital, Tanta University, Egypt. Samples were collected from 30 patients that were clinically diagnosed by the physician's team of the clinic to possess mycotic corneal ulcers. All samples were collected by flamed "Kumara" platinum spatula (Alcon-Couvreur, Belgium) for hard tissues, or by Ethylene gas-sterilized single use cotton swab (BioMed, China) for soft ulcers to avoid perforation. Aseptic conditions of sampling were considered by 1-avoiding conjunctiva and eye lids during corneal scraping; 2- Betadine (Nile Pharma, Cairo, Egypt.) was applied as a gentle washing around infected eyes; 3- samples were isolated in a closed controlled room in the hospital laboratory. Then $\mathrm{C}$-streaks were made on culture plates to distinguish microbial growth of corneal scraping from other plate contaminants (Margo and Brinser, 1987). Each sample was cultured on 2 sterile Petri dishes with sterile Sabouraud's dextrose agar (SDA) medium, One plate was incubated at $27^{\circ} \mathrm{C}$ for 3 days, and the other plate was incubated at $37^{\circ} \mathrm{C}$ for $48 \mathrm{hr}$. Fungal colonies were subcultured for purification, and identification on the same medium under the same incubation conditions.

Another group of fungal cultures was used as archive confirmation for the present survey. Some cultures were previously collected from water samples at the same study area during 2005-2006, identified in Mycology Research Unit, Botany Department, Faculty of Science, Tanta University; and the other cultures were previously isolated from mycotic keratitis, followed up in the Ophthalmology Hospital, Tanta University from patients of the surrounding residential area of our study, represented to in the Ocular Microbiology Unit, Ophthalmology Hospital, Tanta University.

Isolated filamentous fungi were identified morphologically by examination under light microscope at 400X. The identification process was according to Barnett (1972) for the genera of fungi imperfection, Barron (1968) for the genera of Hyphomycetes, Domsch et al. (1980) for compenedium of soil fungi, Ramirez (1982) for Penicillia and Raper and Fennell (1965) for Aspergillus species. The plate count technique was used for the isolation and enumeration 
of yeast (Dutka, 1989). Suspected colonies of yeast were streaked onto Sabouraud dextrose agar plates, and incubated for $48 \mathrm{hr}$ at $37^{\circ} \mathrm{C}$. These cultures were used as the source of inoculum for the yeast confirmatory tests. The isolated yeasts were identified according to Lârone (1995) using API 20 CAUX from Biome rieux SA (France).

Antifungal, Antioxidant Activity and Phytochemical Screening of the Collected Plant Extracts

Leaves of 14 cultivated ornamental and street trees were collected during spring, 2014 from Tanta city, Egypt $\left(30.80^{\circ} \mathrm{N}, 30.99^{\circ} \mathrm{E}\right)$, as shown in Table 1. Some representative plant samples were identified and deposited in the herbarium of Botany Department, Faculty of Science, Tanta University, Egypt (CTANE). Plant materials were air dried and ground to fine powders by electrical mixer. Ten grams of each leaf sample were placed in the Sohxlete and extracted successively with $100 \mathrm{ml}$ of methanol for $48 \mathrm{hr}$. The extracts were evaporated to dryness under reduced pressure using rotatory evaporator at $35^{\circ} \mathrm{C}$, weighed, then stored at $-80^{\circ} \mathrm{C}$. At the experimental time, these extracts were redissolved in $10 \mathrm{ml}$ aqueous methanol (70\%).

TABLE 1. List of selected plants used for antifungal activity screening.

\begin{tabular}{|c|c|c|c|}
\hline Latin name & English name & Family & Arabic name \\
\hline Delonix regia Hook & Royal Poinciana & Fabaceae & 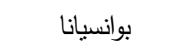 \\
\hline Casuarina equisetifola $\mathrm{L}$. & Horsetail tree & Casuarinaceae & 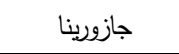 \\
\hline Kigelia africana (Lam.) Benth. & Sausage tree & Bignoniaceae & كيجيليا \\
\hline Ficus sycomorus L. & Sycamore fig & Moraceae & 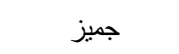 \\
\hline Araucaria heterophylla (Salisb.) Franco & $\begin{array}{l}\text { Norfolk Island } \\
\text { pine }\end{array}$ & Araucariaceae & 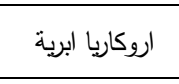 \\
\hline Tamarix aphylla (L.) Karst. & Athel tamarisk & Tamaricaceae & انل \\
\hline Ficus benjamina $\mathrm{L}$. & Benjamin's fig & Moraceae & 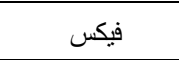 \\
\hline Cassia nodosa $\mathrm{L}$. & Pink Cassia & Fabaceae & كاسيا نودوزا \\
\hline $\begin{array}{l}\text { Melaleuca alternifolia (Maiden \& Betche) } \\
\text { Cheel }\end{array}$ & $\begin{array}{l}\text { Narrow-leaved } \\
\text { tea-tree }\end{array}$ & Myrtaceae & 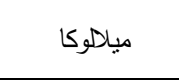 \\
\hline Dalbergia sissoo Roxb. & $\begin{array}{l}\text { North Indian } \\
\text { rosewood }\end{array}$ & Fabaceae & 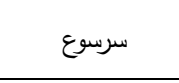 \\
\hline Azadirachta indica A.Juss. & Neem & Meliaceae & نيم \\
\hline Bougainvillea glabra Choisy & Paper flower & Nyctaginaceae & جهنية \\
\hline Magnolia grandiflora $\mathrm{L}$. & Southern magnolia & Magnoliaceae & ماجنوليا \\
\hline Callistemon viminalis (Sol. ex Gaertn.) G.Don & $\begin{array}{c}\text { Weeping } \\
\text { bottlebrush }\end{array}$ & Myrtaceae & فرشاة الزجاج \\
\hline
\end{tabular}

Egypt. J. Bot., 56, No. 3 (2016) 
Cut plug method was employed to determine the antifungal activity of tested extracts (Pridham et al., 1956). The best extracts that showed antifungal activities later were tested to determine the minimal inhibitory concentration against the tested fungi. Serial dilutions were made for selected extracts in order to prepare concentrations of 25, 50, 100, 200 and $300 \mathrm{mg} \mathrm{ml}^{-1}$ of the plant methanolic extract (Shadomy et al., 1985). For studying the effect of Melaleuca alternifolia methanolic leaf extract on the ultrastructure of Trichosporon mucoides and Candida pelliculosa cells, tested microorganism was cultured on the appropriate liquid nutrition medium to get a cell suspension of $5 \times 10^{6}$ cells $\mathrm{ml}^{-1}$, and then mixed with Melaleuca alternifolia methanolic leaf extract of the previously recorded MIC. All the mixture was incubated overnight on a shaking incubator of 60 $\mathrm{rpm}$ at the appropriate temperature. Then treated mixture was centrifuged at $3000 \mathrm{rpm}$ for $20 \mathrm{~min}$, washed with sterile saline solution, re-centrifuged to collect the cell pellet in a clean Eppendorf tube (Richards and Cavill, 1976). Sample was embedded in araldite 502 resin to build a plastic mold (for complete fixation of all cell contents), that were cut into semi-thin sections in the ultra-cut microtome (LEICA ultracut UCT, Japan), stained with $1 \%$ toleudine blue, examined to confirm the success of sample preparation, then ultra-thin sections were prepared, stained with uranyl acetate, and counter stained with lead citrate (Ardenne and Beischer, 1940). Full-stained ultrathin sections were examined, and photographed under the appropriate magnification (at10000X for larger cells of fungi, or 20000X for smaller cells of bacteria), using the transmission electron microscope (JEOL-JEM100SX, Japan) with beam current $=60 \mu \mathrm{A}$, and high voltage of $80 \mathrm{KV}$ and was applied in Electron Microscope Unit at Faculty of Medicine, Tanta University.

The antioxidant capacity of the selected plant extracts were investigated according to Brand-Williams et al. (1995) and Bondet et al. (1997), slightly modified as following: DPPH (2,2 Diphenyl -1-picrylhydrazyl) was shaken vigorously with the extracts and the decrease in absorbance of the resulting solution was monitored at $517 \mathrm{~nm}$ after $1 \mathrm{hr}$. Flavonoids were estimated by calibration curve plotted by quercetin as a standard flavonoid, using Aluminium chloride colorimetric technique (Chang et al., 2002) and expressed as $\mathrm{mg} \mathrm{g}^{-1}$. Total phenolic content was estimated quantitavely using the method described by Jindal and Singh (1975) using FolineCiocalteu's reagent and $\mathrm{Na}_{2} \mathrm{CO}_{3}(20 \%)$. A standard curve by gallic acid was used for the determination of the total phenolic compounds content ( $\mathrm{mg} \mathrm{g}$ -

${ }^{1}$ ). The methanolic leaf extract of Melaleuca alternifolia was subjected for the chemical analysis through gas chromatography / mass spectrum (GCMS) analysis according to Freedman et al. (1986); Fourier transformation Infra-red (FT-IR) analysis (Shimadzu IR affinity 1, Japan) in the Central Lab of Tanta University. 


\section{Results}

Evaluation of Water Physico-Chemical Characters

The present study showed that the mean water temperature recorded during winter (February, 2013) was $\left(19.3{ }^{\circ} \mathrm{C}\right)$, while the mean electrical conductivity (EC) was $775 \mu \mathrm{S} \mathrm{cm} \mathrm{cm}^{-1}$. Sampling point 1 was characterized by the highest value of $\mathrm{pH}$, dissolved oxygen (DO), chemical oxygen demand (COD), ammonia, nitrate and lead; sampling point 2 was characterized by the highest value of ammonia; whereas sampling point 3 was characterized by the highest value of temperature, conductivity, total dissolved solids (TDS) and cadmium (Table 2).

TABLE 2. Evaluation of the water physico-chemical characters (mean \pm SD) of the River Nile at Kafr El-Zayat Industrial Area during winter (2013).

\begin{tabular}{|c|c|c|c|c|c|}
\hline \multirow{2}{*}{\multicolumn{2}{|c|}{ Character }} & \multicolumn{3}{|c|}{ Sampling point } & \multirow{2}{*}{ Mean } \\
\hline & & 1 & 2 & 3 & \\
\hline \multicolumn{2}{|l|}{ Temperature $\left({ }^{\circ} \mathrm{C}\right)$} & 19.2 & 19.2 & 19.6 & $19.3 \pm 0.2$ \\
\hline \multicolumn{2}{|l|}{$\mathrm{EC}\left(\mu \mathrm{S} \mathrm{cm}^{-1}\right)$} & 745 & 786 & 794 & $775.0 \pm 26.3$ \\
\hline \multicolumn{2}{|l|}{$\mathrm{pH}$} & 7.63 & 7.57 & 7.57 & $7.6 \pm 0.03$ \\
\hline \multicolumn{2}{|l|}{ Total dissolved solids } & 395 & 417 & 421 & $411.0 \pm 14.0$ \\
\hline \multicolumn{2}{|l|}{ Dissolved Oxygen } & 3.5 & 2.6 & 2.8 & $2.9 \pm 0.5$ \\
\hline COD & \multirow[t]{3}{*}{$\left(\mathrm{mg} \mathrm{L}^{-1}\right)$} & 33 & 30 & 30 & $31.0 \pm 1.7$ \\
\hline Ammonia & & 8.5 & 8.5 & 8.25 & $8.4 \pm 0.1$ \\
\hline Nitrate & & 6.65 & 6.16 & 6.0 & $6.3 \pm 0.3$ \\
\hline \multicolumn{2}{|l|}{$\mathrm{Cd}^{+2}$} & 0.003 & 0.003 & 0.004 & $0.003 \pm 0.001$ \\
\hline \multicolumn{2}{|l|}{$\mathrm{Pb}^{+2}$} & 0.031 & 0.025 & 0.024 & $0.03 \pm 0.004$ \\
\hline \multicolumn{2}{|l|}{$\mathrm{Hg}^{+2}$} & 0.054 & 0.016 & 0.007 & $0.03 \pm 0.02$ \\
\hline
\end{tabular}

Samplin point $1=$ at the front of Kafr Hashad village.

Samplin point $2=$ a common site after the effluent of all Tala drainage and both companies drains.

Samplin point $3=$ at the entrance of Benover village water treatment station.

Counts of Total Bacteria, Yeasts and Filamentous Fungi Counts

The highest values of TBCs (total bacterial counts) at $37^{\circ} \mathrm{C}$ were 7803 $\mathrm{x} 10^{3} \mathrm{CFU} / \mathrm{ml}$ (Table 3 ), recorded at sampling point 1 . Highest count of fungi (350 colonies $/ \mathrm{ml}$ ) at $27^{\circ} \mathrm{C}$ at station 2 was recorded (Table 3 ). Highest count of yeast $(1480$ colonies $/ \mathrm{ml})$ at $37^{\circ} \mathrm{C}$ was recorded at station 1 during the same season. The most abundant yeasts were Trichosporon mucoides, Candida albicans, Candida pelliculosa and Candida tropicalis, while the most abundant fungi were Aspergillus terreus, Trichoderma viride and Aspergillus niger. During present survey and previous archive collection yeasts and fungi isolated 
from the infected eyes with mycotic keratitis were closely related to that isolated from the water samples (Table 4).

TABLE 3. Total bacterial, yeasts and fungal counts of the River Nile water at Kafr El-Zayat Industrial Area during winter (2013).

\begin{tabular}{|l|l|l|l|}
\hline \multirow{2}{*}{ Station } & \multicolumn{2}{|l|}{ Total Cell Count $\left(\mathbf{C F U m l}^{\mathbf{- 1}}\right)$} \\
\cline { 2 - 4 } & Bacteria $\left(\mathbf{3 7}^{\mathbf{0}} \mathbf{C} \times \mathbf{1 0}^{\mathbf{3}}\right)$ & Yeast $\left(\mathbf{3 7}^{\mathbf{}} \mathbf{C}\right)$ & Fungi $\left(\mathbf{2 7}{ }^{\mathbf{}} \mathbf{C}\right)$ \\
\hline 1- Kafr Hashad village & 7803 & 1480 & 20 \\
\hline $\begin{array}{l}\text { 2- Common industrial } \\
\text { effluent }\end{array}$ & 589 & 20 & 350 \\
\hline 3- Benover village & 151 & 650 & 100 \\
\hline
\end{tabular}

TABLE 4. Distribution of yeast and fungal species in River Nile and infected eyes during the present survey and the previous archive collections.

\begin{tabular}{|c|c|c|}
\hline+2 & River Nile & Infected eye \\
\hline \multicolumn{3}{|l|}{ Yeasts } \\
\hline Rhodotorula glutinis Harrison, 1928 & + & + \\
\hline Candida albicans Berkhout, 1923 & + & + \\
\hline Candida ciferrii Kreger-Van, 1965 & + & + \\
\hline Candida pelliculosa Redaelli, 1925 & + & + \\
\hline Candida tropicalis Berkhout, 1923 & + & + \\
\hline Trichosporon mucoides Bhrend, 1890 & + & + \\
\hline Stephanoascus ciferrii Smith, 1976 & + & + \\
\hline Candida glabrata Anderson, 1917 & + & - \\
\hline Saccharomyces cerevisiae Hansen, 1875 & + & - \\
\hline Candida magnoliae Lodder \& Kreger, 1952 & + & - \\
\hline \multicolumn{3}{|l|}{ Filamentous Fungi } \\
\hline Cladosporium carrionii Link, 1816 & + & + \\
\hline Penicillium marneffei Segretain, 1959 & + & + \\
\hline Aspergillus terreus Thom, 1918 & + & + \\
\hline Aspergillus niger Tieghem, 1867 & + & + \\
\hline Aspergillus tamari Micheli, 1729 & + & - \\
\hline Trichoderma viride Pers., 1794 & + & - \\
\hline Total & 16 & 11 \\
\hline
\end{tabular}

Predisposing Factors of Mycotic Keratitis:

Table 5 revealed that mycotic ulcers were observed to be common among patients aged more than 40 years old ( 18 cases $=60 \%$ out of total mycotic ulcers), and lowered gradually among youth and children to be only 2 cases $(6.7 \%)$ for patients of less than 20 years old. It was noticeable that mycotic keratitis was more common in males $(16$ cases $=53.3 \%)$ more than females $(14$ cases $=46.7 \%)$. Patients holding rural houses possessed higher incidence of mycotic ulcers (19 cases= $63.3 \%)$, more than those in urban houses $(11$ cases $=36.7 \%)$, that was confirmed by the higher incidence of mycotic ulcers $(24$ cases $=80 \%)$ among patients having 
indoor pipes water source than outdoor pumps ( 6 cases $=20 \%)$. Examination of the infected eye showed higher incidence of mycotic infection in the left eye (18 cases $=60 \%)$ than in the right eye $(12$ cases $=40 \%)$.

TABLE 5. Incidence of mycotic ulcers in relation to patient's age and other human life conditions during the present survey.

\begin{tabular}{|l|l|c|c|}
\hline \multicolumn{1}{|c|}{ Parameter } & \multicolumn{1}{c|}{ Category } & No of cases & Percentage (\%) \\
\hline \multirow{3}{*}{ Age } & $<20$ year & 2 & 6.7 \\
& 20-40 year & 10 & 33.3 \\
& $>40$ year & 18 & 60 \\
\hline \multirow{2}{*}{ Gender } & Male & 16 & 53.3 \\
& Female & 14 & 46.7 \\
\hline \multirow{2}{*}{ Type of house } & Rural & 19 & 63.3 \\
& Urban & 24 & 36.7 \\
\hline \multirow{2}{*}{ Water source } & Indoor pipes & 6 & 80 \\
& Outdoor pumps & 12 & 20 \\
\hline \multirow{2}{*}{ Infected eye } & Right & 18 & 40 \\
& Left & 30 & 60 \\
\hline \multicolumn{2}{|c|}{ Total } & & 100 \\
\hline
\end{tabular}

\section{Antifungal Activity of Plant Extracts}

The methanolic extracts of the selected plants were screened for inhibitory efficiency against Candida pelliculosa, Candida tropicalis, Trichosporon mucoides and Aspergillus niger, the most effective methanolic plant extract was Melaleuca alternifolia leaf extract, which gave $19 \mathrm{~mm}$ inhibition zone (Table 6). The minimal inhibitory concentration of Melaleuca alternifolia leaf methanolic extract was recorded at $100 \mathrm{mg} \mathrm{ml}^{-1}$ against Trichosporon mucoides, but $200 \mathrm{mg}$ $\mathrm{ml}^{-1}$ against Candida pelliculosa and Candida tropicalis isolates (Fig. 3).

TABLE 6. General survey for antifungal activity of the tested plant extracts against isolated yeast.

\begin{tabular}{|l|c|c|c|}
\hline \multirow{2}{*}{ Plant } & \multicolumn{3}{c|}{ Mean of inhibition Zone (mm) } \\
\cline { 2 - 4 } & $\begin{array}{l}\text { Candida } \\
\text { pelliculosa }\end{array}$ & $\begin{array}{l}\text { Candida } \\
\text { tropicalis }\end{array}$ & $\begin{array}{l}\text { Trichosporon } \\
\text { mucoides }\end{array}$ \\
\hline Delonix regia & $12 \pm 0.06$ & 0.00 & $12 \pm 0.06$ \\
\hline Casuarina equisetifola & $19 \pm 0.06$ & 0.00 & $17 \pm 0.06$ \\
\hline Ficus sycomorus & 0.00 & 0.00 & $12 \pm 0.00$ \\
\hline Tamarix aphylla & $11 \pm 0.06$ & $11 \pm 0.06$ & $11 \pm 0.00$ \\
\hline Melaleuca alternifolia & $19 \pm 0.00$ & $19 \pm 0.00$ & $19 \pm 0.06$ \\
\hline Azadirachta indica & $15 \pm 0.06$ & 0.00 & $16 \pm 0.06$ \\
\hline Callistemon viminalis $_{\text {Positive control (Fluconazole }}$ & $12 \pm 0.06$ & 0.00 & $13 \pm 0.06$ \\
\hline 20 mg ml ${ }^{-1}$ ) & $20 \pm 0.00$ & $20 \pm 0.00$ & $20 \pm 0.00$ \\
\hline
\end{tabular}




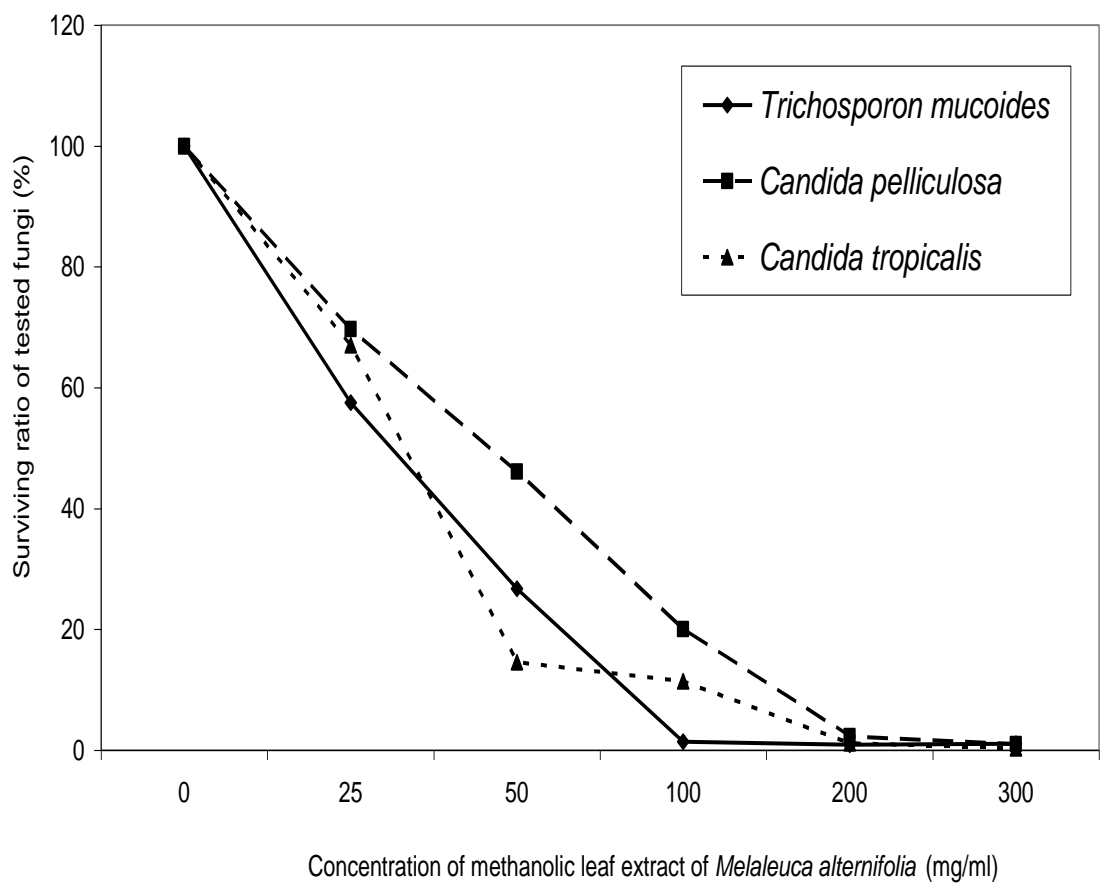

Fig.3. Surviving ratio of the isolated fungal pathogens against Melaleuca alternifolia leaf methanolic extract.

Ultrastructural Examination of Candida pelliculosa and Trichosporon mucoides Treated with Melaleuca alternifolia Methanolic Leaf Extract

Effect of Melaleuca alternifolia leaf methanolic extract on the cell wall and structure of Candida pelliculosa and Trichosporon mucoides under transmission electron microscope were showed in Photos 1 and 2, respectively. Transmission electron micrographs of non-treated (control) cells, showed intact cell wall and cytoplasmic contents, without any foreign precipitations inside, or outside the cell circumstance. Treated cells of Candida pelliculosa showed observable agglutination of nuclear material, lysis of nuclear membrane and dissolving of cellular lipids. Also, rupture of cell wall, perforation of cell membrane and leakage of cell nutrients and soluble contents were recorded. Treated cells of Trichosporon mucoides showed severe destruction of cell wall, agglutination of cell proteins and deformation of cell shape due to leakage of cytoplasmic soluble contents and water. These effects were referred to the antimicrobial activity of Melaleuca alternifolia methanolic leaf extract, where it acted as a protein coagulant, lipid solvent and dehydrating agent due to its high content of phenolic compounds and the presence of other biologically active fatty acids and flavonoids. 


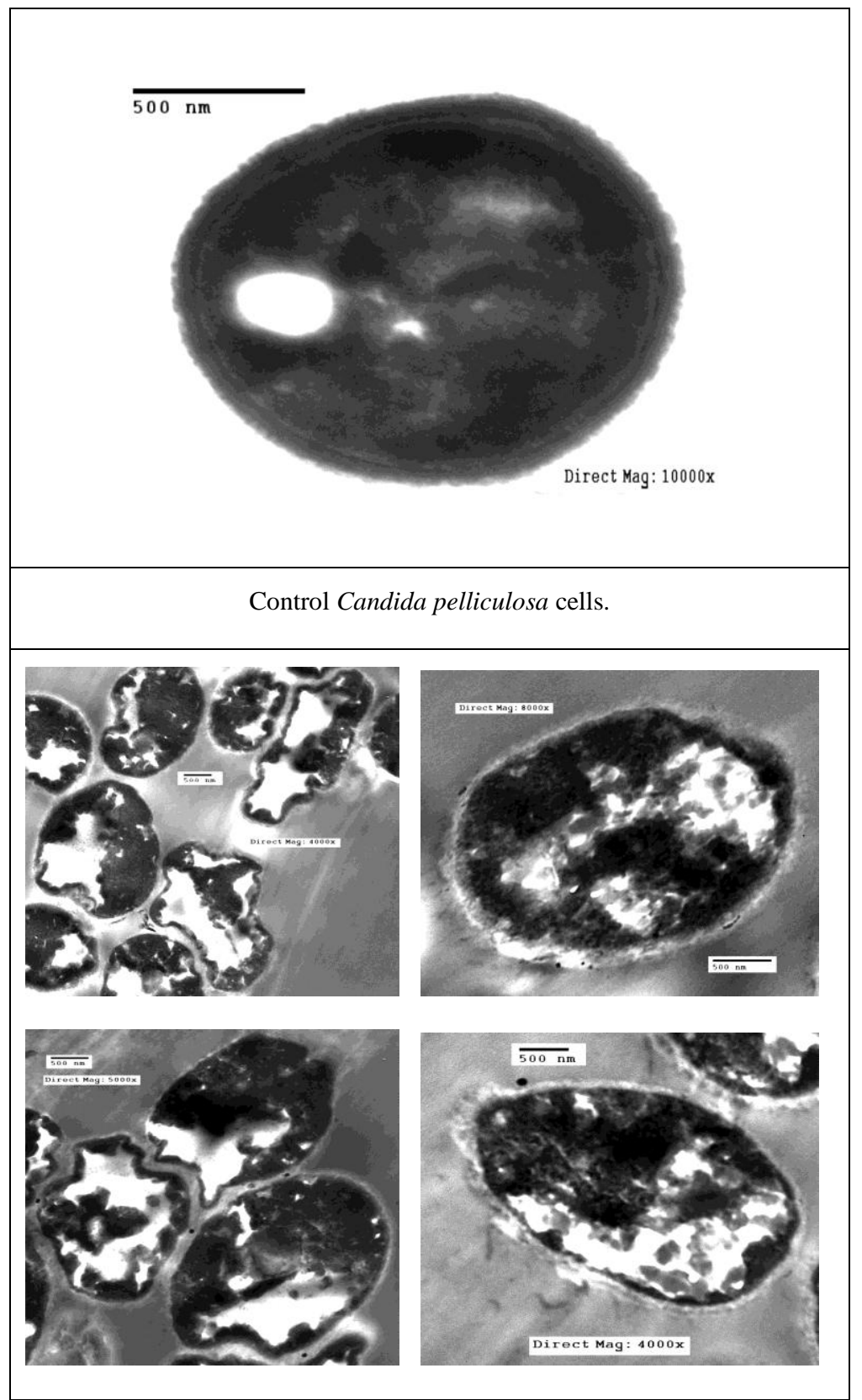

Treated Candida pelliculosa cells.

Photo. 1. Transmission electron micrograph (TEM) of Candida pelliculosa treated with $200 \mathrm{mg} \mathrm{ml}{ }^{-1}$ of Melaleuca alternifolia methanolic leaf extract, compared with control.

Egypt. J. Bot., 56, No. 3 (2016) 


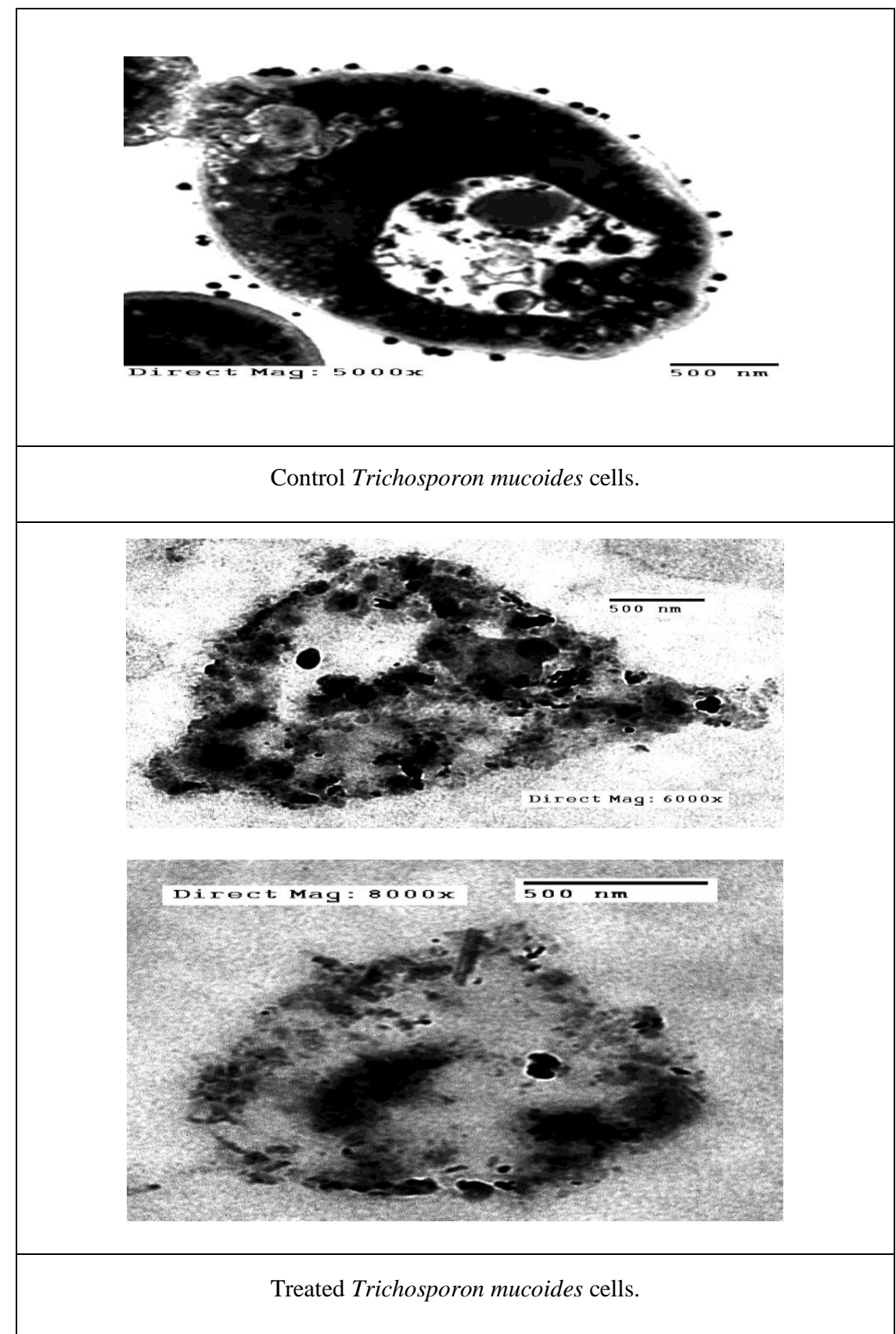

Photo . 2. Transmission electron micrograph (TEM) of Trichosporon mucoides treated with $100 \mathrm{mg} \mathrm{ml}^{-1}$ of Melaleuca alternifolia methanolic leaf extract, compared with control. 
Analysis of Methanolic Leaf Extract of the Selected Plants

Quantitative analysis of the methanolic extract of Melaleuca alternifolia leaves showed that phenolic compounds and flavonoids were found in high concentrations compared with other plant extracts (Table 7). The results of DPPH scavenging activity is relatively compatible with those of total phenolic and flavonoid compounds content, where the highest DPPH activity (95.5\%) was determined in Melaleuca alternifolia which possessed the highest phenolic and flavonoid compounds content 82.6 and $8.79 \mathrm{mg} \mathrm{g}^{-1}$, respectively.

TABLE 7. Antioxidant activity, phenolic compounds and flavonoids content of methanolic plant extracts in the present survey.

\begin{tabular}{|l|l|l|l|}
\hline \multicolumn{1}{|c|}{ Species } & DPPH $(\%)$ & Phenolics $\left(\mathbf{m g ~ g}^{-\mathbf{1}}\right)$ & \multicolumn{1}{|c|}{$\begin{array}{c}\text { Flavonoids } \\
\left(\mathbf{m g ~ g} \mathbf{~}^{-1}\right)\end{array}$} \\
\hline Cassia nodosa & $87.1 \pm 0.8$ & $65.0 \pm 1.0$ & $17.04 \pm 4.29$ \\
\hline Delonix regia & $97.1 \pm 0.1$ & $60.3 \pm 0.7$ & $4.31 \pm 1.33$ \\
\hline Kigelia fricana & $70.8 \pm 7.0$ & $51.0 \pm 0.4$ & $6.36 \pm 0.75$ \\
\hline Ficus sycomorus & $95.4 \pm 0.0$ & $55.5 \pm 0.8$ & $6.11 \pm 0.04$ \\
\hline Callistemon viminalis & $95.4 \pm 0.1$ & $70.0 \pm 1.8$ & $5.71 \pm 0.30$ \\
\hline Azadirachta indica & $78.8 \pm 4.6$ & $62.4 \pm 1.3$ & $21.18 \pm 0.12$ \\
\hline Araucaria heterophylla & $95.0 \pm 0.3$ & $65.5 \pm 0.5$ & $1.99 \pm 0.11$ \\
\hline Melaleuca alternifolia & $95.5 \pm 0.0$ & $82.6 \pm 3.4$ & $8.79 \pm 1.53$ \\
\hline Casuarina equisetifola & $95.3 \pm 0.1$ & $76.3 \pm 2.1$ & $6.16 \pm 0.87$ \\
\hline Bougainvillea glabra & $33.2 \pm 3.6$ & $51.6 \pm 0.3$ & $9.01 \pm 0.57$ \\
\hline Ficus benjamina & $40.7 \pm 1.3$ & $59.3 \pm 0.0$ & $4.43 \pm 0.63$ \\
\hline Tamarix aphylla & $96.0 \pm 0.0$ & $61.3 \pm 1.0$ & $4.52 \pm 0.68$ \\
\hline Magnolia grandiflora & $36.2 \pm 0.4$ & $65.8 \pm 0.3$ & $7.16 \pm 0.54$ \\
\hline Dalbergia sissoo & $64.9 \pm 0.3$ & $50.6 \pm 1.2$ & $15.78 \pm 1.48$ \\
\hline
\end{tabular}

The safety of methanolic extract of Melaleuca alternifolia in the present survey was partialy determined through FT-IR analysis, as shown in Table 8 and Fig. 4. In the FT-IR spectrum the wave number range of 2000-4000 $\mathrm{cm}^{-1}$ showed the absence of toxic cyano $(\mathrm{C} \equiv \mathrm{N})$ group and acetylenic group $(\mathrm{C} \equiv \mathrm{C})$. The selected plant extract was characterized by the presence of aldehyde groups (-CHO) within the wave number range of $2850-2900 \mathrm{~cm}^{-1}$ (all were represented with strong peaks). The composition and identification of the fatty acid components present in the methanolic leaf extract of Melaleuca alternifolia are shown in Table 9 and Fig. 5. Six compounds were identified: the most abundant compounds were octanoic acid methyl ester (25.67\%), 9-Dodecenoic acid, methyl ester, (E) - (24.22\%) and n-Hexadecanoic acid (23.98\%).

Egypt. J. Bot., 56, No. 3 (2016) 
EVALUATION OF ANTIFUNGAL ACTIVITY OF SOME PLANT ...

TABLE 8. Functional group Profile of Melaleuca alternifolia methanolic leaf extract by FT-IR analysis.

\begin{tabular}{|c|c|c|c|}
\hline Functional group & Symbol & $\begin{array}{l}\text { Range of wave } \\
\text { number }\left(\mathrm{cm}^{-1}\right)\end{array}$ & $\begin{array}{l}\text { Presence in } \\
\text { Melaleuca } \\
\text { alternifolia }\end{array}$ \\
\hline Hydroxyl group & $(\mathrm{OH})$ & $3300-3500$ & Present \\
\hline Amino group & $\left(\mathrm{NH}_{3}\right)$ & $3200-3400$ & Absent \\
\hline $\begin{array}{l}\text { Aliphatic saturated hydrocarbon } \\
\text { chains }\end{array}$ & $\left(\mathrm{CH}_{3}, \mathrm{CH}_{2}, \mathrm{CH}\right)$ & $2850-2980$ & Present \\
\hline Aldehyde group & $(\mathrm{CHO})$ & $2850-2900$ & Present \\
\hline Carbonyl group & $(-\mathrm{C}=\mathrm{O})$ & $1700-1750$ & Present \\
\hline $\begin{array}{l}\text { Aliphatic unsaturated hydrocarbon } \\
\text { double bonds }\end{array}$ & $(-\mathrm{C}=\mathrm{C}-)$ & $1500-1600$ & Present \\
\hline Aromatic hydrocarbon ring & -- & $3100-3200$ & Absent \\
\hline Cyano group & $(\mathrm{C} \equiv \mathrm{N})$ & $2000-2250$ & Absent \\
\hline Acetylenic group & $(\mathrm{C} \equiv \mathrm{C})$ & $2000-2250$ & Absent \\
\hline
\end{tabular}

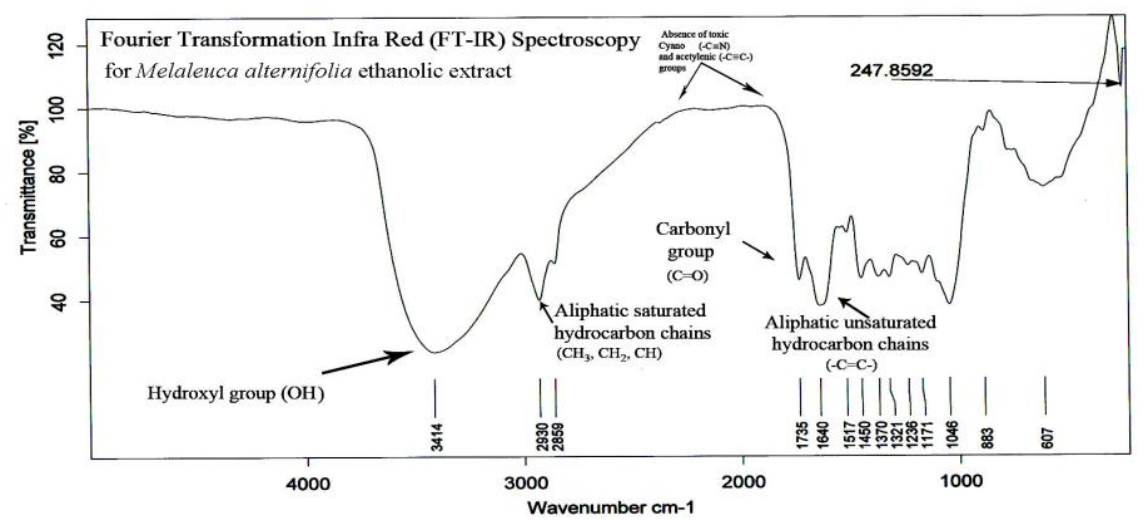

Fig. 4. FT-IR profile analysis for Melaleuca alternifolia methanolic leaf extract.

TABLE 9. GC/MS Profile analysis of Melaleuca alternifolia methanolic leaf extract.

\begin{tabular}{|l|l|l|l|l|l|}
\hline Pk \# & $\begin{array}{l}\text { RT } \\
(\mathbf{m i n})\end{array}$ & Compound Name & $\begin{array}{l}\text { Lipid } \\
\text { number }\end{array}$ & $\begin{array}{l}\text { Peak } \\
\text { Area }\end{array}$ & $\begin{array}{l}\text { Area } \\
(\%)\end{array}$ \\
\hline 1 & 10.52 & Pentanoic acid, methyl ester & C5:0 & 214.22 & 13.93 \\
\hline 2 & 14.86 & Heptanoic acid, methyl ester & C7:0 & 87.143 & 5.67 \\
\hline 3 & 19.41 & Octanoic acid, methyl ester & C8:0 & 394.64 & 25.67 \\
\hline 4 & 51.97 & $\begin{array}{l}\text { Hexadecanoic acid, 15-methyl-, methyl } \\
\text { ester }\end{array}$ & C16:0 & 100.26 & 6.52 \\
\hline 5 & 52.60 & n-Hexadecanoic acid & C16:0 & 368.69 & 23.98 \\
\hline 6 & 54.55 & 9-Dodecenoic acid, methyl ester, (E)- & C12:0 & 372.42 & 24.22 \\
\hline Total & & 1537.37 & 100.00 \\
\hline
\end{tabular}




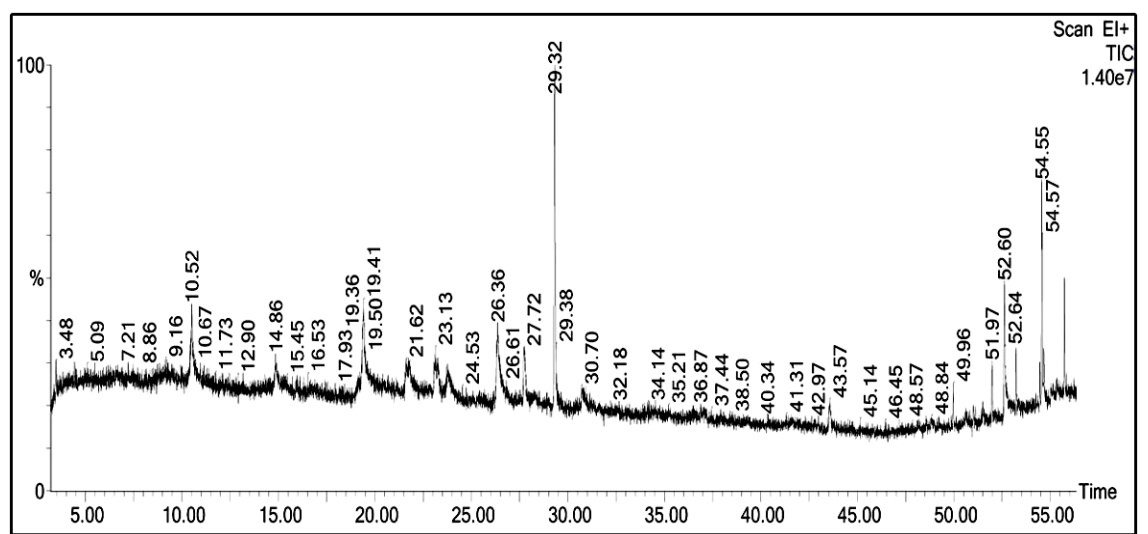

Fig. 5. GC-MS profile analysis for Melaleuca alternifolia methanolic leaf extract.

\section{Discussion}

Variety of wastes effluent, either with or without partial treatment, discharged into the Nile, results in changes in its physical and chemical conditions and microbial quality. Water pollution is one of the most principal environmental and public health problems in River Nile (El-Amier et al., 2015b). Water temperature is an important factor which affects the biological activities of aquatic organisms (Bojanic et al., 2001) and the amount of oxygen that can be dissolved in water. In the present study, elevation of temperature at the entrance site of Benover village water treatment station could be attributed to the discharge of hot waste water (industrial wastes) into the Nile, which consequently induces thermal pollution leading to elevation of temperature. This finding agrees with Bedair (2006). In addition, the high value of EC in the Nile water recorded in the present study may be attributed to the discharge of great amounts of agricultural effluents containing large amounts of dissolved ions and high amount of organic and inorganic constituents from El-Rahawy and Sobol drains. This was previously confirmed by the study of Elewa and Mahdi (1988). The present results indicated also an apparent increase in the water total dissolved solids, this may be attributed to high content of suspended and dissolved matters. River Nile water $\mathrm{pH}$ is always in the alkaline side with slight fluctuations between different stations (Abdo, 2002 and El-Sarnagaway et al., 2010).

The high concentrations of dissolved oxygen (DO) are very vital for aquatic organisms, as it is required for the metabolism of aerobic organisms and organic matter decomposition (Ezzat et al., 2012). Oxygen is also a key component required for all oxidation, nitrification and decomposition processes; and is controlled by three factors: photosynthesis, respiration and exchange at the airwater interface (Krom et al., 1989). Generally, DO concentrations in the Nile are always higher than $7.0 \mathrm{mg} \mathrm{L}^{-1}$, indicating high assimilation capacity (Ezzat et al., 2002). According to APHA (2011), the chemical oxygen demand (COD) Egypt. J. Bot., 56, No. 3 (2016) 
is used as a measure of the oxygen equivalent to organic matter content of a sample that is susceptible to oxidation by a strong chemical oxidant. Generally, during sampling process in winter, the COD value was high at the recorded stations, this may be due to the winter closure which started at the end of December causing decrease in the level of Nile water, leading to elevate the organic load of the Nile during this period.

Reid (1961) reported that ammonia-nitrogen in excess of $1 \mathrm{mg} \mathrm{L}^{-1}$ has been given as an indicator of organic pollution, and could be toxic to aquatic species in concentration over $2.5 \mathrm{mg} \mathrm{L}^{-1}$. Higher concentration of ammonia in the area of the present study could be attributed to organic pollution resulted from domestic sewage, industrial waste and fertilizer runoff. The pronounced increase in $\mathrm{NH}_{3}$ content during winter may be attributed to the decomposed organic matter and dying of algal blooms resulted in increasing of ammonia concentration (Krom et al, 1989). Generally, surface water, not influenced by human activities, contains nitrate concentration less than $5 \mathrm{mg} \mathrm{L}^{-1}$. Excess of 5 $\mathrm{mg} \mathrm{L}^{-1}$ usually indicates pollution by human or animal waste or/and fertilizers run off (Chapman, 1992). At the same time, nitrate is generally the only thermodynamically stable form of nitrogenous compounds in absence of oxygen (Horna, 1972).

Heavy metals have environmental persistence, almost of them have no toxicity at low concentration, but they have ability to incorporate into food chain, and thus it is possible to be concentrated to toxic levels by the aquatic organisms. They are usually divided into two subclasses: $\mathrm{Co}, \mathrm{Cu}, \mathrm{Fe}, \mathrm{Mn}$ and $\mathrm{Zn}$ which are essential for the correct functioning of biochemical processes; and $\mathrm{Hg}, \mathrm{Cd}, \mathrm{Cr}$ and $\mathrm{Pb}$ that have no established biological function and represent the most important contaminants in the aquatic environment. Heavy metal pollution in water is generally associated with agricultural, industrial and municipal discharges (Zaghloul, 2001).

The total bacteria developing at $20-22^{\circ} \mathrm{C}$ are saprophytic types and nonpathogenic to human beings, while those developing at $37^{\circ} \mathrm{C}$ are mainly or potentially parasitic types derived from the soil, sewage, or excretal materials (APHA, 2011). In the present study, the total count of bacteria at $37^{\circ} \mathrm{C}$ was high in winter during the sampling period. However, in Rosetta Branch, Rabeh (2007) reported that the highest bacterial counts $\left(66.8 \times 10^{7}\right.$ and $65.6 \times 10^{7} \mathrm{CFU}$ $\left.\mathrm{ml}^{-1}\right)$ at both incubation temperatures $\left(22\right.$ and $\left.37^{\circ} \mathrm{C}\right)$ were recorded during summer. On the other hand, the highest counts were recorded at Sobol Drain in Menofyia Governorate, while the lowest were at Rosetta Estuary $\left(0.3 \times 10^{7}\right.$ and $0.2 \times 10^{7} \mathrm{CFU} \mathrm{ml}^{-1}$ ). Shaban and El-Taweel (2003) counted Candida albicans and total yeast as indicators of fecal pollution in the River Nile. Concerning yeast species contamination to water, Wojcik et al. (2003) revealed 28 yeast species representing seven genera: Candida, Cryptococcus, Geotrichum, Kloeckera, Rhodotorula, Saccharomyces and Trichosporon in the littoral zone of the Sulejów Reservoir of Poland. Kiziewicz (2004) found that the occurrence 
of Candida albicans and Candida tropicalis was associated with high concentration of ammonium nitrogen and suspended substance. These was closely related to species isolated by El-Sarnagaway et al. (2010) who made total microbial count including fungi and yeasts as indicators for fecal pollution in the River Nile (Rosetta branch) at Kafr El-Zayat Industrial Area during

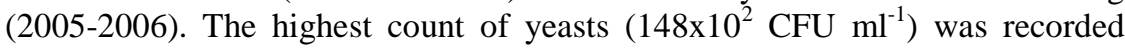
during winter at $37^{\circ} \mathrm{C}$ at about one $\mathrm{Km}$ downstream of El-Malh and Soda Company. The isolated yeasts were Rhodotorula glutinis, Saccharomyces cerevisiae, Candida albicans Candida magnoliae, Candida pelliculosa, Trichosporon mucoides and Candida glabrata. The most common identified fungi were Trichoderma spp., Cladosporium carrionii, Aspergillus tamari, Asperigullus niger and Penicillium marneffei.

Collection of many personal patient data and the recorded medical historic information, indicated that different risk factors were considered to be obvious reasons for the spreading of mycotic ulcers. The present study revealed that the mycotic ulcers were observed to be common among the male patients aged more than 40 years old, that could be explained by increased outdoor activities of males comparing to females in oriental community, which expose males to risks of ocular truma. These findings were relatively close to a previous study in Egypt that recorded a male to female ratio of 9:1 with age range $>40$ years (ALHussaini et al., 1994). Moreover, the study of Moharram et al. (1999) revealed that fungal keratitis affected males more than females, and was more frequent in those aged from 20 to 50 years. It is evident that social hygiene parameters had a great effect on the spreading of infectious human mycotic corneal ulcers. Patients holding rural houses possessed higher incidence of mycotic ulcers. On the other hand, those of higher incidence of mycotic ulcers was recorded among patients having indoor pipes water source than outdoor pumps, theses reflect the bad disinfection of the pipes leading to more growth of infectious organisms. Abu El-Souod et al. (2013) evaluated the spreading of mycotic infection of human corneal ulcers on the basis of the predisposing factors through studying the epidemiology of human mycotic keratitis in Tanta University, Ophthalmology hospital, they revealed that contact lens users and farmers were found to be more susceptible for mycotic keratitis; also immunocompromised male patients aged more than 40 years with rural residence were the most frequent inhabitants of fungal corneal ulcers.

Martin and Ernst (2004) revealed that traditional medicine had made use of many different plant extracts for treatment of fungal infections. Plants produce variety of medicinal components that can inhibit pathogen growth. A considerable number of studies on medicinal plants and alternative compounds, such as secondary metabolites, phenolic compounds, essential oils and extracts, have been performed (Negri et al., 2014). The medicinal plants received an extensive use in traditional system of medicines all over the world, especially in the rural areas, to cure various health problems. The main reasons for the popularity of herbal medicines are 1- plants are near to nature, hence more

Egypt. J. Bot., 56, No. 3 (2016) 
effective than allopathic medicines, 2- they are easily accessible, 3- they are cheaper mode of treatment and 4- show fewer side effects or adverse reactions as compared to modern synthetic drugs (Abbasi et al., 2010). Noumi et al. (2011) detected the chemical composition, antioxidant and antimicrobial potential of Melaleuca alternifolia because it was used as a traditional treatment of fungal infection, its oil has been used medicinally in Australia, due to its antimicrobial (Mondello et al., 2003) and anti-inflammatory (Hammer et al., 2000).

In the present study, phenolics, flavonoids and fatty acids were found in high concentrations, they act as secondary metabolites of Melaleuca alternifolia. The beneficial medicinal and antimicrobial actions of plant resources typically result from the secondary metabolites present in the plant (Jadon and Dixit, 2014). Although, biological activity is usually not attributed to a single compound, but a combination of the metabolites. Wu et al. (2006) have shown that phenolic compounds of a plant origin possessed antioxidative and antimicrobial activities. The antioxidant capacity of phenolics is due to their ability to scavenge free radicals, donate hydrogen atoms or electrons or chelate metal cations (Amarowicz et al., 2004). Many previous studies showed highly positive correlations between the total phenolic compounds, the antioxidant capacity of the plant extracts and the antimicrobial activity (Shan et al., 2007). Adamo et al. (2004) had pointed out that some environmental conditions are capable of breaking the chemical bonds of polyphenols, thereby releasing soluble phenols of low molecular weights, leading to an increase of antioxidant capacity.

The present study revealed that methanolic extract of Melaleuca alternifolia was considered to be effective antifungal agents, its activity has been attributed to the presences of some active functional groups. Sensitivity of Candida pelliculosa and Trichosporon mucoides to the tested plant extract was in the present study was in accordance with that of Noumi et al. (2011).

Many studies have been performed to understand the mechanism of antimicrobial action of fatty acids. It was concluded that fatty acids and their esters exhibited non-specific modes of action (Davidson et al., 2005). The free carboxylic group of the fatty acids is the most important structure required for antimicrobial activity because it allows an optimal insertion into cells that have hydrogen-bond-acceptor groups in the membrane. Hexadecanoic acid was confirmed as antibacterial and antifungal compound (Stojanovi'c et al., 2010). The development of resistance of microbes, including fungi and yeasts, towards antimicrobial agents already in use, necessitates the search for alternative antimicrobials, including fatty acids and their derivatives (e.g. methylated and hydroxyl fatty acids). Although fatty acids may not be as effective as chemical fungicides, they possess less environmental risks. They are not only biodegradable, but exhibit a high degree of specificity. In addition, fatty acids are accepted food additives and importantly, pathogenic fungi are less likely to 
become resistant to antifungal fatty acids. The most important target of antifungal fatty acids is the cell membrane. They cause an increase in membrane fluidity, which will result in leakage of the intracellular components and cell death (Carolina et al., 2011).

\section{Conclusion}

The present study revealed that a high level of chemical and biological contamination was recorded in River Nile at Kafr El-Zayat Industrial Area, Also, it was proved that the infectious diseases, such as mycotic keratities among patients of the surrounding residential area, were closely related to the identified fungal isolates from water samples. A new trial was performed to treat the most common fungal infection (Candida pelliculosa and Trichosporon mucoides) with a natural product (Melaleuca alternifolia methanolic leaf extract) with a promising inhibition rate and effective mode of action.

Acknowledgments: We introduce grateful acknowledgment for efforts of the staff members of Central Lab of Tanta University; Water and Domestic sewage Company Lab; Electron Microscope Unit, Faculty of Medicine, Tanta University; and Prof. Dr.: M. Sameh El-Shourbagy, Professor of Ophthalmology, Faculty of Medicine, Tanta University, for their cooperation to achieve this work.

\section{References}

Abbasi, A., Khan, M., Ahmad, M., Jahan, S. and Sultana, S. (2010) Ethnopharmacological application of medicinal plants to cure skin diseases and in folk cosmetics among the tribal communities of North-West Frontier Province. Pakistan J. Ethnopharmocol., 128: 322-335.

Abdo, M. (2002) Environmental studies on Rosetta Branch and some chemical applications at the area extends from El-Kanter El-Khyria to Kafr El-Zayat City. Ph.D. Thesis, Fac. Sci., Ain Shams Univ., Cairo, Egypt.

Abu El-Souod, S., Mahmoud, Y., El-Shourbagy, M., El-Badry, A. (2013) Epidiomology of Humman Mycotic Keratitis in Tanta University Ophthalmology Hospital, Egypt. J. Exp. Biol. (Bot.), 9 (1): 65-74.

Adamo, M., Capitani, D., Mannina, L., Cristinzio, M., Ragni, P., Tata, A. and Coppola, R. (2004) Truffles decontamination treatment by ionizing radiation. Rad. Phys. Chem., 71: 165-168.

Al-Hussaini, A., Daef, E., El-Shanawany, A. and Abdel-Rahman, M. (1994) Etiology of microbial keratitis. Bull. Ophthalmol. Soc. Egypt., 87: 647-651.

Amarowicz, R., Pegg, R., Rahimi, M., Barl, B. and Weil, J. (2004) Free-radical scavenging capacity and antioxidant activity of selected plant species from the Canadian prairies. Food Chem., 84: 551-562.

Egypt. J. Bot., 56, No. 3 (2016) 
APHA (2011) "Standard Methods for the Examination of Water and wastewater". $22^{\text {nd }}$ ed. American Public Health Association, Washington DC, USA.

Ardenne, M. and Beischer, D (1940) Untersuchung von metalloxyd-rauchen mit dem universal-elekronenmikroskop. Zeitschrift Elektrochemie., 46: 270-277.

Barnett, H. (1972) "Illustrated Genera of Imperfect Fungi". Minneapolis. Burgess Publishing, USA., 241pp.

Barron, G. (1968) The Genera of Hyphomycetes from Soil. Williams and Wilkins Co., Baltimore.

Bedair, S. (2006) Environmental studies on zooplankton and phytoplankton in some polluted areas of the River Nile and their relation with the feeding habit of fish. Ph.D. Thesis, Fac. Sci., Zagazig Univ., Zagazig, Egypt.

Bojanic, N., Solio, M., Krstulovic, N., Marasovic, I., Nincevic, Z. and Vidjak, O. (2001) Seasonal and vertical distribution of the ciliated protozoa and micrometazoa in Kastela Bay (Central Adriatic). Helgoland Marine Res., Springer-Verlag and Awl.

Bondet, V., Brand-Williams, W. and Berset, C. (1997) Kinetics and mechanisms of antioxidant activity using the DPPH free radical method. Lebensm Wiss Technol., 30 (6): 609-615.

Brand-Williams, W., Cuvelier, M., and Berset, C. (1995) Use of a free radical method to evaluate antioxidant activity. Lebensm.-Wiss. U.-Technol., 28: 25-30.

Carolina, H., Johan, L. and Vuyisile, S. (2011) Antifungal free fatty acids: A Review Science against microbial pathogens: Communicating Current Research and Technological Advances, 66-71.

Chang, C., Yang, M., Wen, H. and Chern, J. (2002) Estimation of total flavonoid content in propolis by two complementary colorimetric methods. J. Food Drug Anal., 10: 178-182.

Chapman, D. (1992) "Water Quality Assessments". $1^{\text {st }}$ ed., Chapman and Hall, London, and New York.

Davidson, P., Sofos, J. and Branen, A. (2005) "Antimicrobials in Foods". $3^{\text {rd }}$ ed. CRC Press (Taylor \& Francis Group). Boca Raton., 346-347.

Domsch, K., Gams, W. and Anderson, T. (1980) "Compendium of soil Fungi". Acad. Press, London, 859 pp.

Dutka, B. (1989) "Methods for Microbiological and Toxicological Analysis of Water", waste water and sediments. Burlington. Canada.

El-Amier, Y., El-Kawy, M. and Al-Mamory, S. (2015a) Assessment of the physicochemical characteristics of water and sediment in rosetta branch, Egypt. Journal of Water Resource and Protection, 7:1075-1086. 
El-Amier, Y., Zahran, M. and Al-Mamoori, S. (2015b) Environmental Changes along Damietta Branch of the River Nile, Egypt. Journal of Environmental Sciences, Mansoura University., 44: 235-255.

El-Sarnagaway, W., Shaltout, K., Mahmoud, Y., and Rabeh, S. (2010) Ecomicrobiological study on river Nile at Kafr El-Zayat industrial area. Egyptian Journal of Aquatic Research, 36 (1): 95-106.

Elewa, A. and Mahdi, H. (1988) Some limnological studies on the Nile water at Cairo, Egypt. Bull. Nat. Inst. Oceanogr. and Fish., 14 (2): 141-152.

Ezzat, M., Shehab, H., Hassan, A., El-Sharkawy, M., El- Diasty, A., El- Assiouty, I., El-Gohary, F. and Tczap, A. (2002) Survey of Nile system pollution. Report No. 64. Ministry of Resources and Irrigation, US Agency for International Development, Agricultural Policy Reform Program.

Ezzat, S., Mahdy, H., Abo-State, M., Abd El-Shakour, E. and El-Bahnasawy, M. (2012) Water Quality Assessment of River Nile at Rosetta Branch: Impact of Drains Discharge. Middle-East Journal of Scientific Research, 12: 413-423.

Freedman, B., Butterfield, R. and Pryde, E. (1986) Transesterification kinetics of soybean oil. J. Am. Oil Chem. Soc., 63: 1375-1380.

Ghallab, M. (2000) Some physical and chemical changes on River Nile down stream of Delta Barrage at El-Rahawy drain. M. Sc. Thesis, Fac. Sci, Ain Shams Univ., Cairo, Egypt.

Gorden, J. (1999) "External Eye Infections". Gorden, J. Ed., Community Eye Health.

Hammer, K., Carson, C. and Riley, T. (2000) Melaleuca alternifolia (tea tree) oil inhibits germ tube formation by Candida albicans. Med. Mycol., 38: 355-362.

Horna, R. (1972) Marine chemistry. Wiley Interscience, London.

Jadon, R. and Dixit, S. (2014) Phytochemical extraction and antimicrobial activity of some medicinal plants on different microbial strains. J. Medicinal Plants Stud., 2 (3): $58-63$.

Jindal, K. and Singh, R. (1975) Phenolic content in male and female Carica papaya: A possible physiological marker for sex identification of vegetable seedlings. Physiol. Plant., 33: 104-107.

Keay, L., Edward, K., Naduvilath, T. and Taylor, H. (2006) Microbial keratitis, predisposing factors and morbidity. Ophthalmology, 113: 192-198.

Kiziewicz, B. (2004) Candida albicans, Candida aquatica, Candida krusei and Candida tropicalis strains isolated from springs of Podlasie Province. Wiad Parazytol., 50 (3): 535-544.

Egypt. J. Bot., 56, No. 3 (2016) 
Krom, M., Neori, A. and Van Rijn, J. (1989) Importance of water flow rate in controlling water quality processes in marine and fresh water fishponds. Israel. $J$. Aquacul. Goldman J., Tenore R., Ryther H., 41, 23-33.

Lârone, D. (1995) "Medically Important Fungi; A guide to Identification", $3^{\text {rd }}$ ed, ASM Press, Washington D.C.

Margo, C. and Brinser, J. (1987) "Microbiologic Diagnosis: Mycology". In: Laboratory Diagnosis in Ophthalmology, Brinser J Ed., McMillan, New York.

Martin, K. and Ernst, E. (2004) Herbal medicines for treatment of fungal infections: a systematic review of controlled clinical trials. Mycoses, 47 (3-4): 87-92.

Moharram, A., Abdel-Kader, M., Al-Hussaini, A. and Al-Ghalibi, S. (1999) Studies on mycotic keratitis in Assiut Governorate. Proceeding of 2nd International Conference On Fungi. Hopes and Challenges, Cairo, Egypt., 1: 133-146.

Mondello, F., De, B., Girolamo, A., Salvatore, G. and Cassone, A. (2003) In vitro and in vivo activity of tea tree oil against azole-susceptible and - resistant human pathogenic yeasts. J. Antimicrob. Chemother., 51 , 1223-1229.

Negri, M., Salic, T., Shinobu-Mesquita, C., Capoci, I., Svidzinski, T. and Kioshima, E. (2014) Early state Research on antifungal Natural products. Molecules, 19: 29252956.

Noumi, E., Sonoussi, M., Hajlaoui, H., Trabelsi, N., Ksouri, R., Valentin, E and Bakhrouf, A. (2011) Chemical composition, antioxidant and antifungal potential of Melaleuca alternifolia (tea tree) and Eucalyptus globulus essential oils against oral Candida species. Journal of Medicinal Plants Research, 5(17): 4147-4156.

Pridham, T., Lindenfelser, L., Shotwell, O., Stodola, F., Benedict, R., Foley, C., Jacks, P., Zaumeyer, W., Perston, W. and Mitchell, J. (1956) Antibiotics against plant diseases: A laboratory and green house survey. Phytopathology, 46: 568-575.

Rabeh, S. (2007) Monitoring of microbiological and sanitary quality of water in Rosetta Branch of the River Nile, Egypt. J. Egypt. Acad. Soc. Environ. Develop., 8 (4): 5770 .

Ramirez, C. (1982) "Manual and Atlas of Penicillia". Elsevier Biomedical Press, Amsterdam.

Raper, K. and Fennell, D. (1965) "The Genus Aspergillus". Williams and Wilkins Co., Baltimore.

Reid, K. (1961) "Ecology of Inland Waters and Estuaries. Text book VNR, New York.

Richards, R. and Cavill, R. (1976) Electron microscope study of effect of benzalkonium chloride and edentate disodium on cell envelope of Pseudomonas aeruginosa. J. Pharm. Sci., 65: 76-80. 
Rodrick, J. (2000) The mycosis. In: "Hunter's Tropical Medicine and Emerging Infectious Diseases", Thomas, S. Ed., WB Sounders Co., Boston.

Shaban, A. and El-Taweel, G. (2003) Microbiological monitoring and evaluation of River Nile water at Cairo segment and Ismailia Canal. Egyptian Journal of Microbiology, 38 (2): 169-182.

Shadomy, S., Epsinel, I. and Cartwright, R. (1985) Laboratory studies agents: Susceptibility test and bioassays. In: "Manual of Clinical Microbiology", Lennette A, Balows W., Hausler H. and Shadomy S. $4^{\text {th }}$ ed. of: Little Brown Co, Boston.

Shan, B., Cai, Y., Brooks, J. and Corke, H. ( 2007) The in vitro antibacterial activity of dietary species and medicinal herb extracts. Int J Food Microbiol., 117:112-119.

Shukla, P. and Singh, P. (1997) Advances in Medical Mycology, Council for Advances in Biosources \& Research Perfecting Co., Lucknow, India.

Stojanovi'c-Radi'c, Z., Comi'c, L., Radulovi'c, N., Deki'c, M., Randelovi'c, V., Stefanovi'c, O. (2010) Antibacterial Activity of naturally occurring compounds from selected plants. Chem. Pap., 64: 368-377.

Tanure, M., Cohen, E., Sudesh, S., Rapuane, C. and Laibson, P. (2000) Spectrum of fungal keratitis at Wills Eye Hospital, Philadelphia, Pennsylvania. Cornea., 19: 307312.

Wojcik, A., Rozga, A. and Kurnatowski, P. (2003) Prevalence of potentially pathogenic fungi in the bathing sites of the Sulejow Reservoir. Wiad Parazytol., 49(2): 173-185.

Wu, C., Chen, F., Wang, X.; Kim, H. (2006) Antioxidant constituents in Tanacetum parthenium extract and their chromatographic quantification. Food Chem., 96: 220227.

Zaghloul, H. (2001) Usage of Zinc and Calcium in Inhibiting the Toxic Effect of Copper on the African Carfish, Clarias gariepinus. Egyptian German Society of Zoology, 35: 99-120.

(Received 27/6/2016; Accepted 1/8/2016) 
EVALUATION OF ANTIFUNGAL ACTIVITY OF SOME PLANT ...

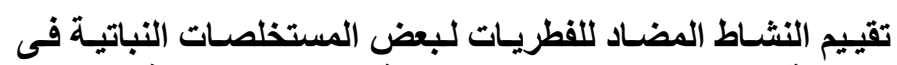
مواجهة عدوى الإلتهاب الفطرى لقرنية الإنسان المرتبطة بالمياه

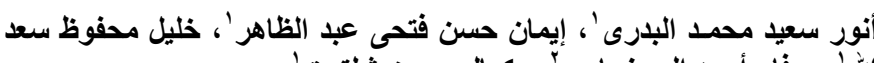

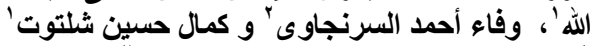

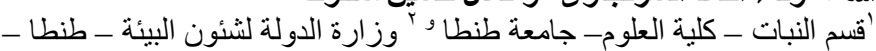

تتسبب المستويات المرتفعة لملوثات مياه النيل فى تغيير حاد لمؤشرات التلوث

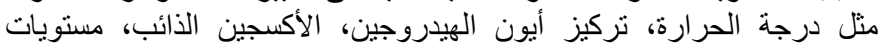

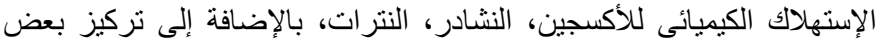

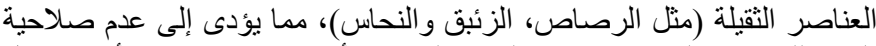

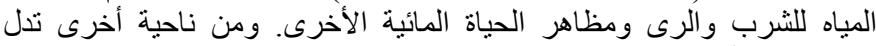

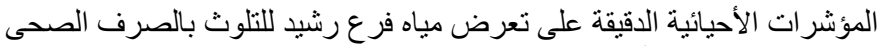

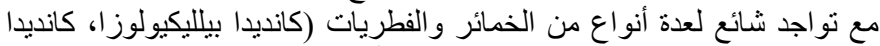

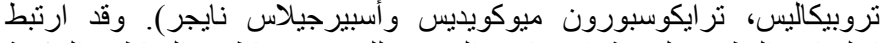

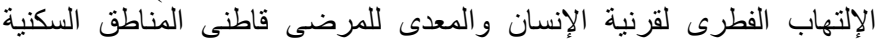

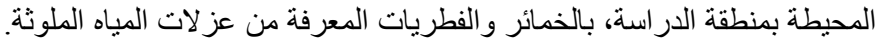

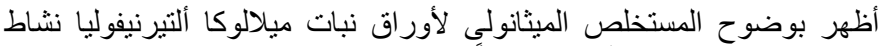

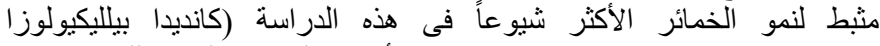

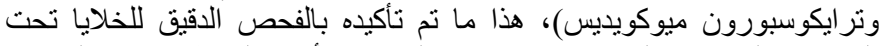

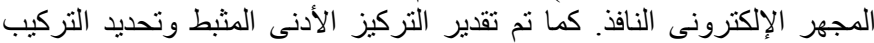

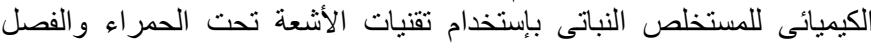

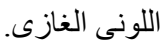

